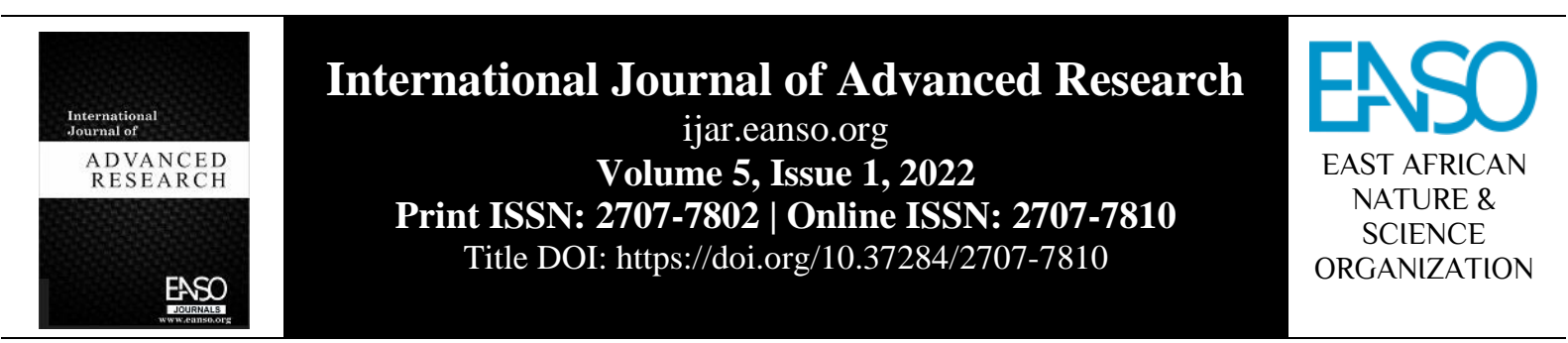

Original Article

\title{
Analysis of Doctoral Supervision
}

\author{
Joyce J. Lelei ${ }^{1 *}$ \\ ${ }^{1}$ Egerton University. P. O. Box 536-20115, Egerton, Kenya. \\ * Author for Correspondence ORCID ID: https://orcid.org/0000-0003-3110-3638; Email: joycendemo@ gmail.com.
}

Article DOI: https://doi.org/10.37284/ijar.5.1.562

\section{Publication Date: ABSTRACT}

23 February 2022 Sustainable development goal four is to ensure quality education by 2030 . One Keywords: target of achieving this is by 2020 , substantially expand globally the number of scholarships available to developing countries, in particular least developed

Africa, countries, small Island developing States and African countries, for enrolment Doctoral in higher education. There has been an increased enrolment in doctoral studies Education at African Universities in the recent years. Government industry and business Supervision, are interested in high quality graduates. The study aimed to contribute to the Quality. quality of doctoral graduates by assessing their perception of supervision.

Quality. Perception of supervision was obtained using the Postgraduate Research Experience Questionnaire (PREQ). The study recommends (i) self-evaluation of supervisors. This will point out weak areas in supervision and when corrected will ensure quality of graduates, and (ii) conduct tracer studies of doctorate graduates.

\section{APA CITATION}

Lelei, J. J. (2022). Analysis of Doctoral Supervision. International Journal of Advanced Research, 5(1), 21-29. https://doi.org/10.37284/ijar.5.1.562

\section{CHICAGO CITATION}

Lelei, Joyce J. 2022. “Analysis of Doctoral Supervision.” International Journal of Advanced Research 5 (1), 21-29. https://doi.org/10.37284/ijar.5.1.562.

\section{HARVARD CITATION}

Lelei, J. J. (2022) “Analysis of Doctoral Supervision.”, International Journal of Advanced Research, 5(1), pp. 21-29. doi: 10.37284/ijar.5.1.562.

\section{IEEE CITATION}

J. J. Lelei, “Analysis of Doctoral Supervision.”, IJAR, vol. 5, no. 1, pp. 21-29, Feb. 2022.

\section{MLA CITATION}

Lelei, Joyce J. “Analysis of Doctoral Supervision.”. International Journal of Advanced Research, Vol. 5, no. 1, Feb. 2022, pp. 21-29, doi:10.37284/ijar.5.1.562.

\section{INTRODUCTION}

Sustainable development goal four is to ensure quality education by 2030 (United Nations, n.d.). One target of achieving this is "by 2020, substantially expand globally the number of scholarships available to developing countries, in particular least developed countries, Small Island developing States and African countries, for enrolment in higher education" (United Nations, 
n.d., p.21). Egerton University is a recipient of several postgraduate scholarships. These include the World Bank Centre of Excellence in sustainable agriculture and agribusiness management, the Regional Forum for Capacity Building in Agriculture and the African Development Bank scholarship for training of university and technical training institutes teaching staff in agricultural and livestock biosciences and agro-processing. The scholarships, obtained in the past five years, have attracted several African agricultural science doctoral students to the university.

Majority of supervisors in the field of agricultural science at Egerton University are guiding their first doctoral students. The quality of their supervision practice has not been examined. In agreement with the study by Lee (2008), supervisor approach to supervision is "influenced by own concept of research supervision or experience as a doctoral student" (p. 267). Bastalich (2017) analyzed supervision literature and observed "little critique of existing supervision practice". He pointed out that the work supervisors do "is either assumed or cautioned against, but not explored" (p. 1148).

Assessing supervision practice and addressing weak points can result in better relationship between student and supervisor (Bastalich, 2017). This practice ultimately produces quality graduates.

\section{Statement of the Problem}

Lack of information on supervision perception among agricultural science doctoral students of Egerton University. The supervision approach to supervision has not been critiqued.

\section{Study Objective}

To contribute to quality of doctorate graduates by appropriate supervision. The specific objective of the study was to assess perception of agricultural science doctoral students on their supervision. It was further hypothesised that supervision perception is low among agricultural science doctoral students.

\section{Justification}

Poor quality postgraduate education negatively impacts research and development (Kigotho, 2018). Governments, business, and industry are interested in "high quality doctoral graduates to provide leadership and a competitive national advantage in an internationalized market place" (Halse, 2007, p.326). Interventions to improve supervision cannot be made in the absence of information on supervision perception.

\section{LITERATURE REVIEW}

\section{Quality of Higher Education}

The fourth sustainable development goal is to "ensure inclusive and equitable quality education and promote lifelong learning opportunities for all" (United Nations, n.d., p. 21). Targets to achieve this goal include "by 2030, ensure equal access for all women and men to affordable and quality technical, vocational and tertiary education, including university" (United Nations, n.d., p. 21), and "substantially increase supply of qualified teachers through international cooperation for teacher training in developing countries, especially least developed countries and small island developing States" (United Nations, n.d., p. 22).

Higher education quality and policy is promulgated in many countries as indicated by the Education Quality Accreditation Commission (2019). In the United Kingdom, a qualification characteristics statement describes the distinctive features of the doctorate. It indicates that universities are responsible for quality assurance (Quality Assurance Agency for Higher education [QAA] doctoral degree characteristics statement, 2015). The commission of university education in Kenya (2014) has provided standards and guidelines to ensure quality of academic programmes in Kenyan Universities. One function of Egerton University is to participate in knowledge discovery, transmission and preservation (Egerton University Act, 2012). The commitment of both supervisor and student contributes to a $\mathrm{PhD}$ with reasonable quality (Sahay, 2015).

\section{Roles of the Supervisor}

In a video presentation, Student Minds (2019) indicated that:

"The role of the supervisor is to; support the student complete his postgraduate studies, guide and inform students on where to find information, have a clear goal or picture in mind on what needs to be done and help the 
student to reach it, be an advisor and provide counselling when the student is in need of help. The supervision style is very important and depends on the need of the student. Certain students have expectations and need security [to be reassured] while others need more freedom. Some subjects require more guidance while there is possibility of leaning back in some subjects."

Gatfield (2005) developed a conceptual model using experiences of 12 supervisors from an Australian University in the social science discipline. These individuals were considered excellent in their supervisory skills on basis of "achieving high completion rates; having candidates submit within the normally expected time frame; engaging in multiple supervisions and receiving excellent supervisory reports" (p. 319). The model differentiated the four operating styles of supervisors:

"Laissez-faire style, the supervisor is nondirective and not committed to high levels of personal interaction. He may appear uncaring and uninvolved; Pastoral style, the supervisor provides considerable personal care and support but not necessarily in a task-driven directive capacity; Directional style, the supervisor has a close and regular interactive relationship with the candidate, but avoids non-task issues; Contractual style, the supervisor is able to administer direction and exercises good management skills and interpersonal relationships". (p. 317-318).

Although Gatfield (2005) concludes that "the most preferred style was contractual" (p. 321), he points out that "attitudes and responses" of the candidate influences preferred style and "there is intermeshing of operating style that involves the candidate to some measure" (p.318). It is suggested that there should be some flexibility. Some students prefer to work independently but there are those who need more guidance and reassurance from the supervisors. Gatfield (2005) recommended a workshop on training supervisors on these styles especially for those in the apprentice stage of becoming supervisors. It is suggested that such training should be accompanied by attaching novice supervisors to experienced ones, in a co-supervision approach, in order to boost their confidence. In most cases novice supervisors are left to navigate supervision on their own and apply "own experience as a doctoral student", also observed by Lee (2008, p 267). This compromises quality of supervision.

Lee, Dennis, and Campbell (2007) encourage selfevaluation of supervision based on certain attributes (Table 1). It is suggested that this evaluation can point out weak areas in supervision and when corrected can ensure quality of graduates.

Table 1: Supervisor self-evaluation

\begin{tabular}{|c|c|c|c|}
\hline $\begin{array}{l}\text { Activity } \\
\text { /Strategy }\end{array}$ & Question/Task & $\begin{array}{l}\text { What } \\
\text { could you } \\
\text { do better? }\end{array}$ & $\begin{array}{l}\text { Appreciating } \\
\text { individual } \\
\text { differences }\end{array}$ \\
\hline $\begin{array}{l}\text { Appreciating individual } \\
\text { differences }\end{array}$ & $\begin{array}{l}\text { Give a case study that illustrates your } \\
\text { recognition of individual differences. }\end{array}$ & & \\
\hline Availability & $\begin{array}{l}\text { Give an example of the strategy you use to } \\
\text { be available to your PhD students. }\end{array}$ & & \\
\hline Critical Thinking & $\begin{array}{l}\text { Describe how you last used active } \\
\text { questioning to lead a PhD student towards a } \\
\text { solution or coming up with a new idea }\end{array}$ & & \\
\hline Enthusiasm & $\begin{array}{l}\text { Give an example of how you showed } \\
\text { enthusiasm about your } \mathrm{PhD} \text { students' } \\
\text { research as you are about your own. }\end{array}$ & & \\
\hline $\begin{array}{l}\text { Building a scientific } \\
\text { community }\end{array}$ & $\begin{array}{l}\text { Describe a strategy for trying to build a } \\
\text { scientific community in your group. }\end{array}$ & & \\
\hline $\begin{array}{l}\text { Building a social } \\
\text { community }\end{array}$ & $\begin{array}{l}\text { Describe a strategy you use to build your } \\
\text { group as a social community }\end{array}$ & & \\
\hline
\end{tabular}




\begin{tabular}{lll}
\hline $\begin{array}{l}\text { Activity } \\
\text { /Strategy }\end{array}$ & Question/Task & $\begin{array}{l}\text { What } \\
\text { could you } \\
\text { do better? }\end{array}$ \\
\hline Skill development & $\begin{array}{l}\text { Appreciating } \\
\text { individual } \\
\text { differences }\end{array}$ \\
& $\begin{array}{l}\text { Describe steps you take to develop the } \\
\text { critical, writing and presentation skills of } \\
\text { your PhD candidate. }\end{array}$ & \\
\hline Networking & $\begin{array}{l}\text { Give an example of how you have } \\
\text { introduced each of your PhD students into } \\
\text { the scientific network of your research area }\end{array}$ \\
\hline Mentor for life & $\begin{array}{l}\text { How many of your past PhD graduates are } \\
\text { you in contact with? }\end{array}$ & \\
\hline
\end{tabular}

Source: Lee, Dennis \& Campbell (2007)

\section{Assessing Perception of Supervision}

Lee (2008) suggests specific questions to assess perception of supervision. They include; what is your supervision experience? What do you discuss in meetings? What are expectations of students? What problems did your student face and how were they solved?

Mainhard et al. (2009) recommended use of Postgraduate Research Experience Questionnaire (PREQ) as a valuable instrument for measuring perception of supervision. The PREQ was "developed in 1999 by the Graduate Careers Council of Australia through literature review and focus groups with higher degree research (HDR) candidates" (Radloff et al., 2017, p.10).

The PREQ was updated in 2017 by the Australian Council of Educational Research (Radloff et al., 2017). A "five-point scale" is used to obtain responses to questions on "supervision, intellectual climate, infrastructure, goals and expectations, skill development, thesis examination and industry engagement" (Radloff et al., 2017, p.11). The PREQ was adapted for use in the current study as it encompasses key supervisory attributes.

\section{METHODOLOGY}

Questionnaires (Appendices A and B) were sent by email to two soil science doctorate students, in
December 2019. The sample size was limited to two doctoral students, of both genders. They were selected because they were at the tail end of their studies and considered representative of doctoral students in a selected agricultural science programme. The total doctoral students in the selected programme are four.

They both filled and returned the questionnaires by email. Recommendations to improve supervisory practice were made based on information on doctoral education found in referred journal articles and course materials of the DIES/CREST Training Course for Supervisors of Doctoral Candidates at African Universities by Stellenbosch University, held from October $14^{\text {th }} 2019$ to January $23^{\text {rd }}, 2020$.

\section{RESULTS AND DISCUSSION}

The results of the survey are presented in Tables 2 and 3.

\section{Student Information}

\section{Age, Gender and Time Spent on the Doctorate}

The agricultural science doctoral students, named A and B, are enrolled at Egerton University, of both gender and above forty years of age (Table 2). 
Table 2: Characteristics of doctoral students

\begin{tabular}{lll}
\hline Characteristic & Student A & Student B \\
\hline Age bracket & $41-50$ & $41-50$ \\
Gender & Male & Female \\
University & Egerton University & Egerton University \\
Year of admission & 2016 & 2017 \\
Time spent (months) & 44 & 26 \\
Progress & Thesis examination & Data collection \\
Choice of PhD topic & Student initiative & Student initiative \\
Supervisor allocation & Department & Graduate school \\
Doctorate format & Research and thesis & Research, thesis and coursework \\
Motivation for pursuing & Interest in research and & Interest in research and pursue a career in \\
the doctorate degree & pursue a career in academia & academia and research outside academia \\
\hline
\end{tabular}

The doctoral students A and B have spent 44 and 26 months on their studies, and are at thesis examination and data collection stages, respectively (Table 2). In Kenya, the Commission for Higher Education (2014) provides standards and guidelines for university academic programmes. One guideline for the doctoral degree studies is that it "shall extend for at least three academic years" (p.49). An academic year, for postgraduate studies at Egerton University, comprises two semesters of seventeen weeks each. The period allowed for the doctorate degree at Egerton University is four academic years. The students are therefore on track to complete their doctorate degrees within this period. Time to the doctorate is an indicator of quality supervision and quality of the doctorate, as explained by Bitzer (2016) and Gatfield (2005).

\section{Motivation for Pursuing the Degree}

The students are pursuing the doctorate degree because of an interest in research and also to pursue a career in academia (Table 2). This agrees with the QAA doctoral degree characteristics statement (2015), a component of the UK Quality Code for Higher Education. It indicates that acquisition of this degree enables the holder to teach at the university or work in specific field.

\section{Doctoral Standard}

The doctorate degree pursued is either by research and thesis or research, thesis, and course work (Table 2). The approaches differ among the students because one had registered for the doctorate programme before implementation of the doctoral degree guidelines by Commission for University Education (2014). The current $\mathrm{PhD}$ is by research, thesis, and course work. It applies to students that registered for the programme from 2017 onwards.

In Egerton University, the thesis can be in two formats. The first is in form of a flowing monograph, but with the requirement of publication of at least two articles from their study in referred journals and one conference paper. The second format is thesis by publication, where the thesis consists of a compilation of referred journal articles, from their doctorate study. This format also requires that the student presents a paper from their research in a conference. Stellenbosch University, with a long history of research, also has these two forms of thesis (Frick, 2016). The Egerton University students are required to have these articles published before they can be allowed to defend their theses. This has driven some students to publish in predatory journals as a quick fix. The university should step in by providing a list of credible journals to the students and allow them to only show evidence of paper acceptance to meet the requirement for defence. Publication in credible journals takes time because of the many applications they receive.

Concern for quality assurance can arise when a thesis is by publication as argued by Hoddell et al. (2002). The doctoral thesis examination panel at Egerton University are often at a dilemma on how to interrogate the work, when already published. The approach taken by the UK in assessing published work can be adapted at Egerton University, where "published works are assessed for their originality, rigour and significance by representatives of the relevant discourse community, the referees and editors of academic journals and books" (Bradley, 2009, p.332). Quality assurance should include "eligibility of candidates themselves, the actual nature of the 
submission, the supervision received as well as the assessment procedures of the award" (Bradley 2009, p.332).

\section{Perception on Supervision}

Perceptions of doctoral students on their supervision was based on several criteria presented in Table 3.

\section{Supervision, Skills Development and Industry Engagement}

The students strongly agreed or agreed that their skills were developed, had received helpful feedback on their progress and good guidance on topic selection and refinement from their supervisors and that efforts were made by to understand the problems they faced (Table 3 ). The doctoral students are mature and had clear goals and expectations. It is suggested that these attributes contributed to a positive supervisory relationship. They strongly agreed that they could apply their skills in Industry and had made professional connections outside the university sector.

Ul Hadi and Muhammad (2017) indicted that supervisor should assist students to identify the research topic, monitor their progress and provide feedback, assist them to interpret data, inform them of their responsibilities and assist in planning the research, develop students' research skills, keep them on track, and offer advice on personal problems

Table 3: Perception of agricultural science doctorate students $(n=2)$ on their supervision

\begin{tabular}{|c|c|c|}
\hline \multicolumn{2}{|c|}{ Supervision perception } & Response \\
\hline \multirow[t]{2}{*}{ Supervision } & $\begin{array}{l}\text { Supervisor(s) provided good guidance on topic selection and } \\
\text { refinement. }\end{array}$ & $\begin{array}{l}100 \% \\
\text { agreed }\end{array} \quad$ strongly \\
\hline & $\begin{array}{l}\text { My supervisor(s) made a real effort to understand difficulties } \\
\text { I faced, my supervisor(s) provided additional information } \\
\text { relevant to my topic, and my supervisor(s) provided helpful } \\
\text { feedback on my progress. }\end{array}$ & $\begin{array}{l}50 \% \text { agreed, } \\
50 \% \text { strongly agreed }\end{array}$ \\
\hline \multirow[t]{2}{*}{$\begin{array}{l}\text { Intellectual } \\
\text { climate }\end{array}$} & $\begin{array}{l}\text { The department provided a good seminar programme, the } \\
\text { department provided opportunities for social contact with } \\
\text { other postgraduate students and the department provided } \\
\text { opportunities for involvement in the broader research culture. }\end{array}$ & $\begin{array}{l}50 \% \text { neither agreed } \\
\text { nor disagreed, } \\
50 \% \text { agreed }\end{array}$ \\
\hline & $\begin{array}{l}\text { I was integrated into the department's community and the } \\
\text { research environment in the department or faculty stimulated } \\
\text { my work. }\end{array}$ & $\begin{array}{l}50 \% \text { agreed } \\
50 \% \text { strongly agreed }\end{array}$ \\
\hline \multirow[t]{3}{*}{$\begin{array}{l}\text { Skill } \\
\text { Development }\end{array}$} & $\begin{array}{l}\text { My research further developed my problem-solving skills, I } \\
\text { developed my skills in critical analysis and evaluation, as a } \\
\text { result of my research I feel confident about tackling } \\
\text { unfamiliar problems, I gained confidence in leading and } \\
\text { influencing others, I improved my ability to design and } \\
\text { implement projects effectively and I developed my } \\
\text { understanding of research integrity (e.g., rigour, ethics, } \\
\text { transparency, attributing the contribution of others). }\end{array}$ & $\begin{array}{l}50 \% \text { agreed } \\
50 \% \text { strongly agreed }\end{array}$ \\
\hline & $\begin{array}{l}\text { I improved my ability to plan and manage my time } \\
\text { effectively. }\end{array}$ & $\begin{array}{l}50 \% \text { neither agreed } \\
\text { nor disagreed, } \\
50 \% \text { strongly agreed }\end{array}$ \\
\hline & $\begin{array}{l}\text { I improved my ability to communicate information effectively } \\
\text { to diverse audiences. }\end{array}$ & $100 \%$ agreed \\
\hline \multirow[t]{2}{*}{ Infrastructure } & I had access to a suitable working space. & $\begin{array}{l}50 \% \text { neither agreed } \\
\text { nor disagreed } \\
50 \% \text { strongly agreed }\end{array}$ \\
\hline & I was able to organize good access to necessary equipment. & $\begin{array}{l}50 \% \text { neither agreed } \\
\text { nor disagreed, } \\
50 \% \text { agreed }\end{array}$ \\
\hline
\end{tabular}




\begin{tabular}{|c|c|c|}
\hline \multicolumn{2}{|c|}{ Supervision perception } & \multirow{2}{*}{$\begin{array}{l}\text { Response } \\
50 \% \text { agreed, } 50 \% \\
\text { strongly agree }\end{array}$} \\
\hline & $\begin{array}{l}\text { I had good access to the technical support I needed, I had good } \\
\text { access to computing facilities and services and there was } \\
\text { appropriate financial support for research activities. }\end{array}$ & \\
\hline $\begin{array}{l}\text { Goals and } \\
\text { Expectations }\end{array}$ & $\begin{array}{l}\text { I developed an understanding of the standard of work and I } \\
\text { understood the required standard for the thesis. }\end{array}$ & $\begin{array}{l}50 \% \text { agreed, } \\
50 \% \text { strongly agree }\end{array}$ \\
\hline \multirow[t]{2}{*}{$\begin{array}{l}\text { Industry } \\
\text { engagement }\end{array}$} & $\begin{array}{l}\text { I am confident I can apply my skills outside the university } \\
\text { sector and I had opportunities to develop professional } \\
\text { connections outside the university sector. }\end{array}$ & $\begin{array}{l}100 \% \\
\text { agreed }\end{array}$ \\
\hline & $\begin{array}{l}\text { I had opportunities to work on research problems with real- } \\
\text { world or industry application. }\end{array}$ & $\begin{array}{l}50 \% \text { agreed, } \\
50 \% \quad \text { strongly } \\
\text { agreed. }\end{array}$ \\
\hline $\begin{array}{l}\text { Overall } \\
\text { Satisfaction }\end{array}$ & $\begin{array}{l}\text { I was satisfied with the quality of my higher degree research } \\
\text { experience response. }\end{array}$ & $50 \%$ strongly agreed \\
\hline $\begin{array}{l}\text { Contextual } \\
\text { Items }\end{array}$ & $\begin{array}{l}\text { Did you participate in other types of work-integrated learning } \\
\text { (e.g., placements, practicums, consultancies, industry } \\
\text { research projects) as part of your programme? }\end{array}$ & $\begin{array}{l}50 \% \text { strongly } \\
\text { disagreed, } \\
50 \% \text { agreed. }\end{array}$ \\
\hline
\end{tabular}

Adapted from Postgraduate Research Experience Questionnaire (PREQ) by Radloff et al (2017).

\section{Infrastructure and Intellectual Climate}

The students agreed or strongly agreed that they had access to computer facilities, financial and technical support (Table 3). The students are on scholarships therefore able to purchase laptops and obtain technical support. The World Bank African centres of excellence, African Development Bank, and Regional Forum for Capacity Building in Agriculture support majority of the agricultural science doctoral students at Egerton University.

There was $50 \%$ agreement that there was availability of suitable working space and necessary equipment. Sitting space can be created innovatively by for example putting up coverings in open spaces between laboratories or convert some lecture halls into offices. An agricultural science complex will be built in the near future. There was 50\% neutral response concerning opportunities for social interaction. Common sitting spaces can help build interactions and support among the students. Although there was $50 \%$ neutral response regarding provision of seminars, the students are required to take a seminars course. It is one of the courses in the agricultural science doctoral curriculum. They are also encouraged to attend seminars given by visiting or local professors.

\section{Participation in Work Integrated Learning}

There was 50\% strong disagreement for their participation in placements, practicums, consultancies, industry research projects. The fourth principle on innovative doctoral training by the European Commission advocates for "exposure to industry and other relevant employment sectors" (Tsakonas, 2016, p.21). It is suggested that an internship course can be introduced in the curriculum. This will help students acquire necessary knowledge and skills. In some cases, students conduct their research projects or laboratory analysis in institutions outside the university. The students also assist in teaching of undergraduate courses.

\section{Thesis Examination}

The students did not respond to questions related to thesis examination. They are at the data collection and thesis submission stages. It is suggested that the thesis can show quality of the supervision and achievement of programme learning outcomes.

\section{RECOMMENDATIONS}

\section{Include other Departments in the Survey}

Two students were selected in the current study. However doctoral students from all programmes of Egerton University should be included in a future survey, preferably after thesis examination. 


\section{Tracking of Graduates}

The International Association of Universities (IAU) final report advices universities to monitor the progression of doctorate graduates (van't Land, 2011). This can give information on "external perception of the institution, of doctoral programmes offered and their valuation by public and private sectors" (van't Land, 2011, p.41).

In the United States of America, the Nation Science Foundation's (NSF) "Survey of Doctorate Recipients (SDR) provides longitudinal career history information for holders of research doctorates in science, engineering of health (SEH) fields" (Ortega and Kent, 2018, p.33). According to the authors, this helps universities to prepare students for the job market.

\section{REFERENCES}

Australian Council for Education Research \& Department of Education, Training and Youth Affairs, Higher Education Division, Evaluations and Investigations Program, (2000). Evaluation and validation of the trial postgraduate research experience questionnaires. Canberra: The Council. 150p

Bastalich, W. (2017). Content and context in knowledge production: a critical review of doctoral supervision literature. Studies in Higher Education, 42(7), 1145-1157. https://eric.ed.gov/?id=EJ1139897

Bitzer, E. (2016). Research into Doctoral Education: A Survey of Institutional Research Projects in Southern Africa. In J. Botha \& N.J. Muller (eds.). Institutional Research in South Africa Higher Education: Intersecting Contexts and Practices. Stellenbosch: SUN PRESS. 277 297. https://doi.org/10.18820/97 81928357186/14.

Badley, G. (2009). Publish and be doctor-rated: the $\mathrm{PhD}$ by published work. Quality Assurance in Education, 17(4), 331- 342. https://doi.org/ $10.1108 / 09684880910992313$

Commission for University Education (2014). Universities standards and guidelines. https://www.cue.or.ke

Lee, Dennis \& Campbell (2007). "How good a supervisor are you? self-assessment exercise".
Education Quality Accreditation Commission. (2019). Education quality. https://www.accre ditation.info

Egerton University Act Revised Edition 2012 [1988] Published by the National Council for Law Reporting with the Authority of the Attorney-General. Retrieved from http://www.kenyalaw.org.

Frick, L. 2016. PHD by Publication: An Institutional Analysis. In M. Fourie-Malherbe, R. Albertyn, C. Aitchison \& E. Bitzer. (eds.). Postgraduate Supervision: Future Foci for the Knowledge Society. Stellenbosch: SUN PRESS. 299- 312. https://doi.org/10.18820/97 $81928357223 / 18$.

Gatfield, T. (2005). An Investigation into PhD Supervisory Management Styles: Development of a dynamic conceptual model and its managerial implications. Journal of Higher Education Policy and Management, 27(3), 311- 325, https://doi.org/ $10.1080 / 13600800500283585$

Halse, C. (2007). Is the doctorate in crisis? Nagoya Journal of Studies in Higher Education, 7, 321- 337. http://hdl.handle.net/ 10536/DRO/DU:30035159

Hoddell, S., Street, D. \& Wildblood, H. (2002). Converging or diverging patterns of provision", Quality Assurance in Education, 10(2) 61- 70. https://doi.org/10.1108/0968488 0210423546

Kigotho, W. (2018). Higher education - Caught in a double bind. University World News: African Edition.

Lee, A. (2008). How are doctoral students supervised? Concepts of doctoral research supervision. Studies in Higher Education, 33(3), 267- 281. https://doi.org/10. 1080/03075070802049202.

Mainhard, T., van der Rijst, R., van Tartwijk J. \& Wubbels, T. (2009). A model for the supervisor-doctoral student relationship. High Educ, 58, 359-373. https://doi.org/10.1007/s 10734-009-9199-8

Ortega, S.D, Kent, J. D. (2018). What is a PhD? Reverse-Engineering Our Degree Programs in the Age of Evidence-Based Change, Change. 
The Magazine of Higher Learning, 50(1), 3036.

QAA characteristics statement (2015). UK quality code for higher education. Retrieved from https://www.qaa.ac.uk

Radloff A., Matthews, D., Bibby, Y. \& Edwards, D. (2017). Final report. Review of the Postgraduate Research Experience Questionnaire (PREQ). Australian Council for Educational Research, p.94

Sahay, A. (2015). Doctoral Degree in India: The Need for Transformation. In H., Lal (Ed). Transforming Indian Higher Education. p. 235-255. Bloomsbury.

Student Minds (2019). What is the role of the supervisor? YouTube. https://www.youtube.c om

Tsakonas, F. (2016). Overview of doctoral training in the EU. Workshop and Seminar within REDOS (Reforming doctoral studies at the University of Montenegro) "Doctoral Studies: Knowledge Transfer from EU Partners with Training of the Trainers", given in Podgorica, 30.11.2016. - 02.12.2016. https:// www.redos.ac.me/Montenegro

Ul Hadi, N. \& Muhammad B. (2017). Role of Supervisor in the Performance of Postgraduate Research Students. Journal of Research and Reflections in Education December 2017, 2, pp 178-186 http://www.ue.edu.pk/jrre

United Nations (n.d). Transforming Our World: The 2030 Agenda for Sustainable Development. New York: UN Publishing. Retrieved from https://www.sustainabledevel opment.un.org

van't Land, H. (2016). The changing nature of doctoral studies in Sub-Saharan Africa: Challenges and policy development opportunities at six universities in SubSaharan Africa. Paris, International Association of Universities. 